\title{
Characterization and evaluation of hydrological processes responsible for spatiotemporal variation of surface water quality at Narmada estuarine region in Gujarat, India
}

\author{
Nirmal Kumar • Pankaj Kumar • George Basil • \\ Rita N. Kumar • Ali Kharrazi • Ram Avtar
}

Received: 11 January 2014/ Accepted: 1 April 2014/Published online: 13 April 2014

(C) The Author(s) 2014. This article is published with open access at Springerlink.com

\begin{abstract}
This study is an effort to trace the spatiotemporal variation in water at Narmada estuarine region through solute concentration. A total of 72 water samples were collected and analyzed from three sampling points along with in situ measurement of tidal height at monthly basis for 2 years. Result shows that spatiotemporal variation of water quality occurs because of the following main mechanisms, i.e., carbonate weathering, dilution and seawater-freshwater mixing. Firstly, points situated toward inland showing the simple dilution effect on receiving high amount of monsoonal precipitation. Secondly, tidal fluctuation pattern has a strong influence on the water quality taken from the point located in near proximity to the coast. Finally, it can be concluded that water quality shows a different response, in accordance with the different tidal phase and the distance from the sea.
\end{abstract}

Keywords Narmada estuarine region .

Seawater-freshwater (SW-FW) mixing · Tidal fluctuation

N. Kumar · P. Kumar $(\bowtie) \cdot$ G. Basil · R. N. Kumar Institute of Science and Technology for Advance Studies and Research (ISTAR), Vallabh Vidyanagar 388120, Gujarat, India e-mail: pankajenvsci@gmail.com

\section{A. Kharrazi}

Graduate School of Public Policy, University of Tokyo, 7-3-1

Hongo, Bunkyo-ku, Tokyo 113-0033, Japan

R. Avtar

United Nations University, Institute for Sustainability and Peace (UNU-ISP), Shibuya-ku, Tokyo 150-8925, Japan

\section{Introduction}

Coastal zones, especially low-lying deltaic areas (within 60 $\mathrm{km}$ of the shoreline) accommodate about $50 \%$ of the world population, so it is very important to know hydrological processes at coastal aquifers. Estuaries are important coastal ecosystems which occur where there is a confluence of fresh and marine environments and create a salinity gradient from the inner to outer estuary (Prandle 2009). Cameron and Pritchard (1963) defined an estuary as a semi-enclosed coastal body of water which has free connection with the open sea and within which seawater is measurably diluted with freshwater derived from land drainage. Fairbridge (1980) defined it as an inlet of the sea reaching into a river valley as far as the upper limit of tidal rise, normally being divided into three sections: the upper estuary, dominated by freshwater; the middle estuary, an area dominated by brackish water deriving from a seawater and freshwater mixing; the lower estuary, maintaining free connection with the sea, composed by marine water. Estuaries have been called the "nurseries of the sea" because the protected environment and abundant food provide an ideal location for organisms to inhabit and reproduce (De Souza 1983). Estuaries form vital habitats for thousands of marine species and are important for the health of the oceans because they filter sediment and pollutants from the water before it flows into the oceans. Excess nutrients are removed in bordering salt marshes, resulting in cleaner water for people and marine organisms.

Different mixing states can exist in an estuary at any moment over space and at different times at the same place. The mixing is neither uniform nor steady. It is non-uniform because the ratio of salt to freshwater increases as the estuary grows in cross-section seaward. The mixing is unsteady, because of variations in the height and strength 


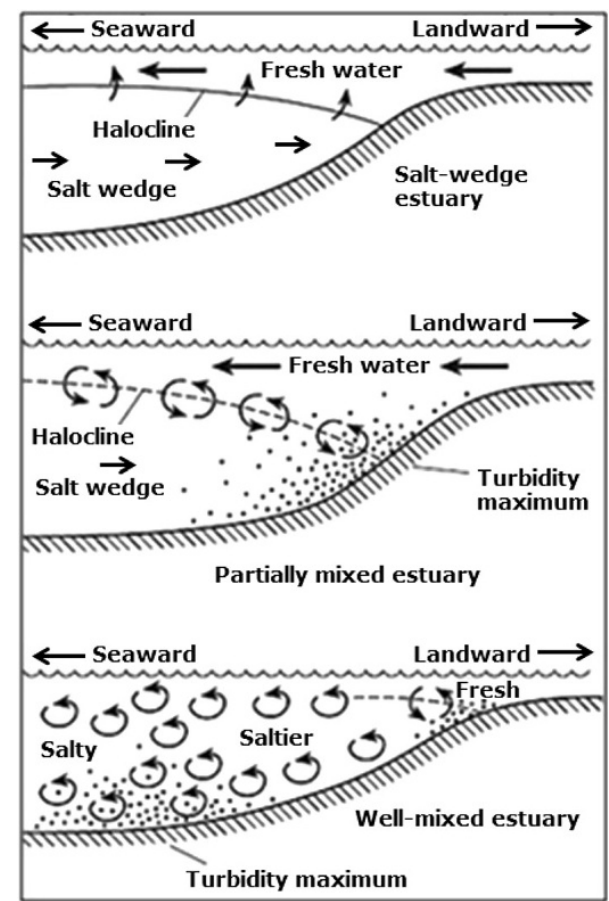

Fig. 1 Different mixing types at any typical estuarine region

of the tide, especially on semidiurnal, diurnal and springneap scales and because of seasonal and storm-related changes in river discharge. For these reasons, estuaries can be classified into three main types, depending on the mixing type: salt wedged, partially mixed and well mixed (Chen and Sanford 2009) (Fig. 1).

The concentration of dissolved constituents in estuaries is far more variable than oceanic waters, varying both temporally (daily, seasonally and inter-annually) and spatially (with increasing distance from the mouth), with depth and laterally. The nutrient chemistry of an estuarine ecosystem is complex and dynamic due to anthropogenic perturbations and reactions in the tidally mixed zone of strong redox gradients (Wen et al. 2008).

Mechanism of seawater-freshwater mixing has been extensively studied through array of environmental isotopes and chemical tracers (Jorgensen et al. 2008; Langman and Ellis 2010; Kumar et al. 2013). Interaction between tidal water fluctuation and coastal groundwater quality is important to understand the different aspects of beach stability, seawater intrusion and beach ecosystem (Grant 1948; Harbison 1986; Li et al. 1997). Turner (1993) stated that existence of capillary fringe above water table in coastal aquifer helps for inland propagation of tidal waves. Different studies have proved that tidal fluctuation has significant impact on both surface water and ground water qualities in coastal areas (Abdullah et al. 1997; Kumar et al. 2012). Recently, many studies have also focused on estuarine environment to understand the problem of nutrient mobilization related to salt water intrusion (Eagling et al. 2012; Wong et al. 2013). Salt water intrusion at estuarine region is being affected by various meteorological parameters, viz. precipitation and wind intensity (Manca et al. 2014). These studies also broaden the knowledge base of scientific community about the importance of studying tidal affinity with groundwater-surface water interaction. As seen from the above-cited review work, despite a lot of importance, very few attempts have been taken to understand spatiotemporal variation of water quality at estuarine region. Considering the above facts, this work was intended to elucidate spatiotemporal variation of surface water quality with special reference to SW-FW mixing pattern in the dynamic estuarine system of Narmada, Gujarat.
Fig. 2 Narmada estuarine region with sampling points (Landsat TM5 image of 23/10/ 2009)

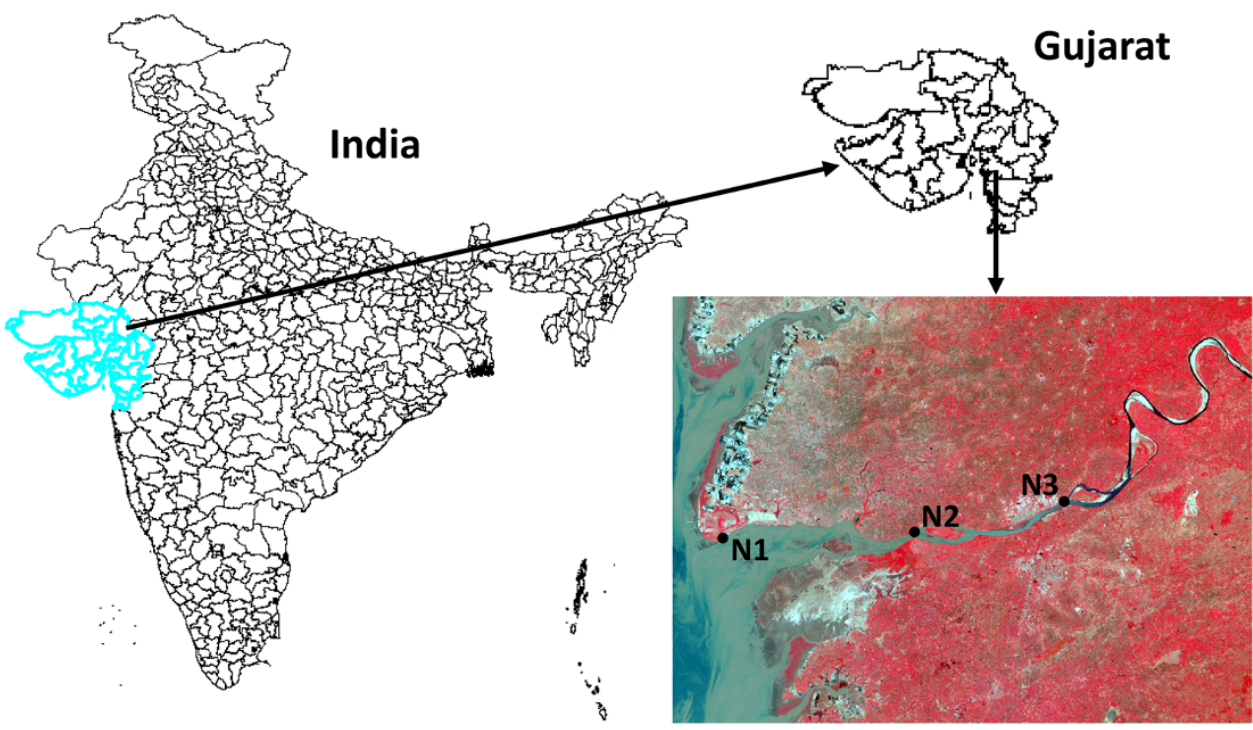


Fig. 3 Elevation map of Narmada estuarine region

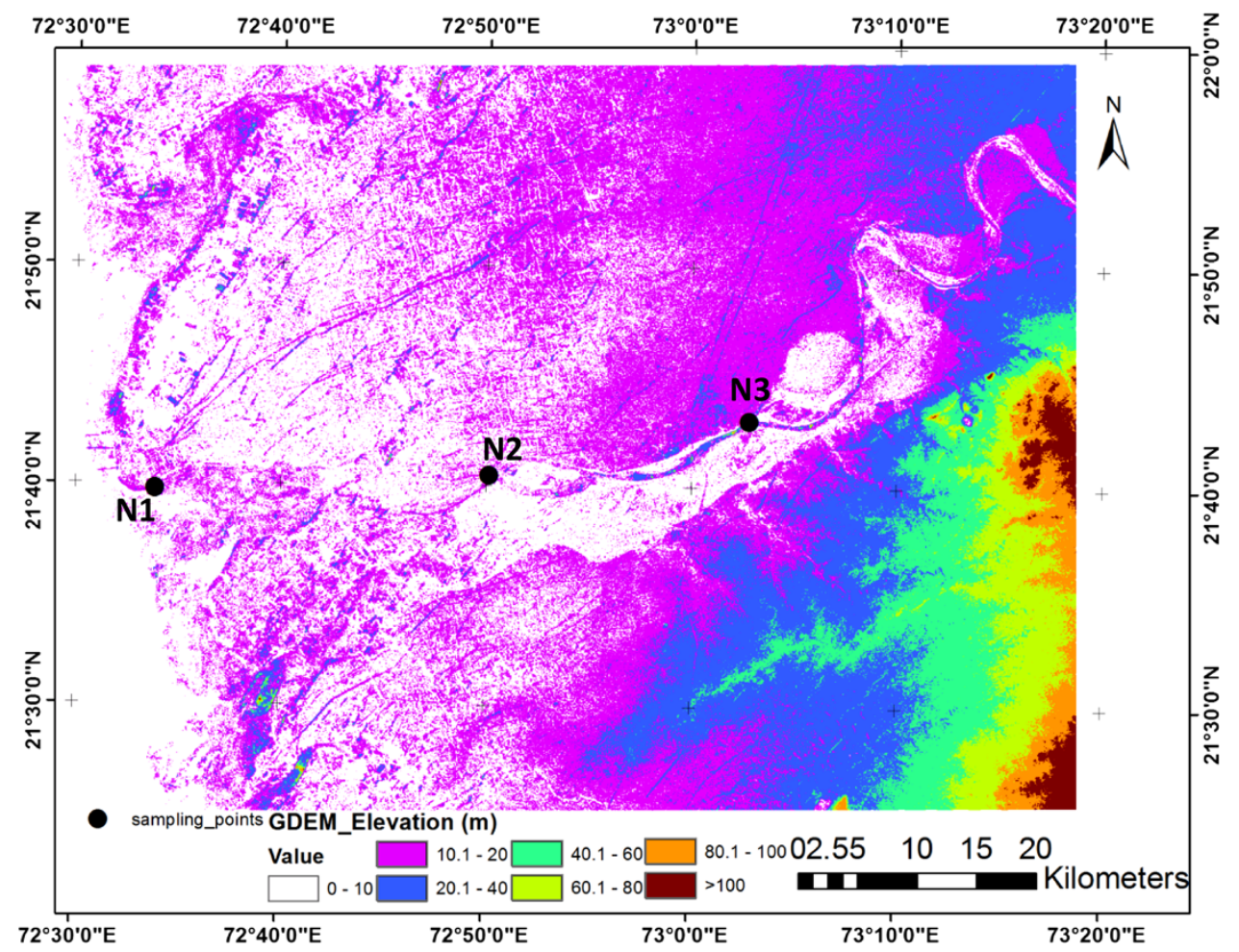

\section{Study area}

Narmada estuarine region, which consists of a major part of Gulf of Khambhat, is located between $21^{\circ} 20^{\prime}-22^{\circ} 00^{\prime} \mathrm{N}$ latitude and $72^{\circ} 30^{\prime}-73^{\circ} 20^{\prime} \mathrm{E}$ longitude, in Gujarat state, India (Fig. 2). The funnel-shaped 72-km-long estuarine occupies an area of $6,346 \mathrm{~km}^{2}$. The height of the channel above mean sea level in the region at shallow (mouth of the estuary) and deep (toward head of the estuary) points varying between 5 and $20 \mathrm{~m}$, respectively (Fig. 3). Relief gradient of the region when approaching from coastal region toward inland can also be found from the elevation map of the Narmada estuarine area (i.e., Fig. 3). Land use/ land cover (LU/LC) map of the study area is shown in Fig. 4. It is found that whole area is being divided into seven major categories, viz. wetland, buildup, agricultural land, current fallow land, scrub land, plantation and flood plain zone. Geologically upstream basin area of Narmada River flow composed of basaltic terrains of the Deccan Traps while that at downstream area is alluvial deposits composed of carbonaceous sandstone before entering the Gulf of Cambay. The southwest monsoon brings rainfall, and about $70 \%$ of the rainfall occurs during the period from June to September. The relative humidity of the region ranges between 65 and $85 \%$. The seasonal temperature variation in the area ranges from 10 to $44{ }^{\circ} \mathrm{C}$ during the winter and summer, respectively. The estuarine environment is characterized by low and patchy primary production. Macrobenthic population is sparse with low biomass, poor fishery production and mangroves in discontinuous patches (ICMAM 2002).

Channel flow from this estuarine carries heavy load of suspended sediments into the Gulf of Khambhat. High tidal influence and nearly flat coastal terrain result in submergence of large areas during flood tide and lead to vast mudflats particularly along the eastern shore and some of these areas also sustain mangrove habitats.

\section{Methodology}

Three sampling sites (Ambata, Bhadbuth and Zadeshwar which are herein after referred as N1, N2 and N3, respectively) were selected in such a way that they represent different geological formations, land use patterns and seawater-freshwater interaction at varying topography of the Narmada estuarine region as shown in Fig. 4. These sampling sites are $20 \mathrm{~km}$ apart starting from coastal site and covering up to $40 \mathrm{~km}$ inland region. One water sample was collected on the 15th day of every month for 2 years, from each representative sampling location. So a total of 24 surface water samples were collected from each site in the time span of 2 years ranging from July 2008 to June 2010. Tidal and precipitation data for this 2-year time span are being recorded from tide gauge and rain gauge located at Dediapada and Karjan, respectively.

In situ measurements for $\mathrm{EC}, \mathrm{pH}$ and temperature were conducted using an Orion Model Number, 01915. After

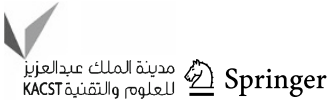


Fig. 4 Land use/land cover map of Narmada estuarine region

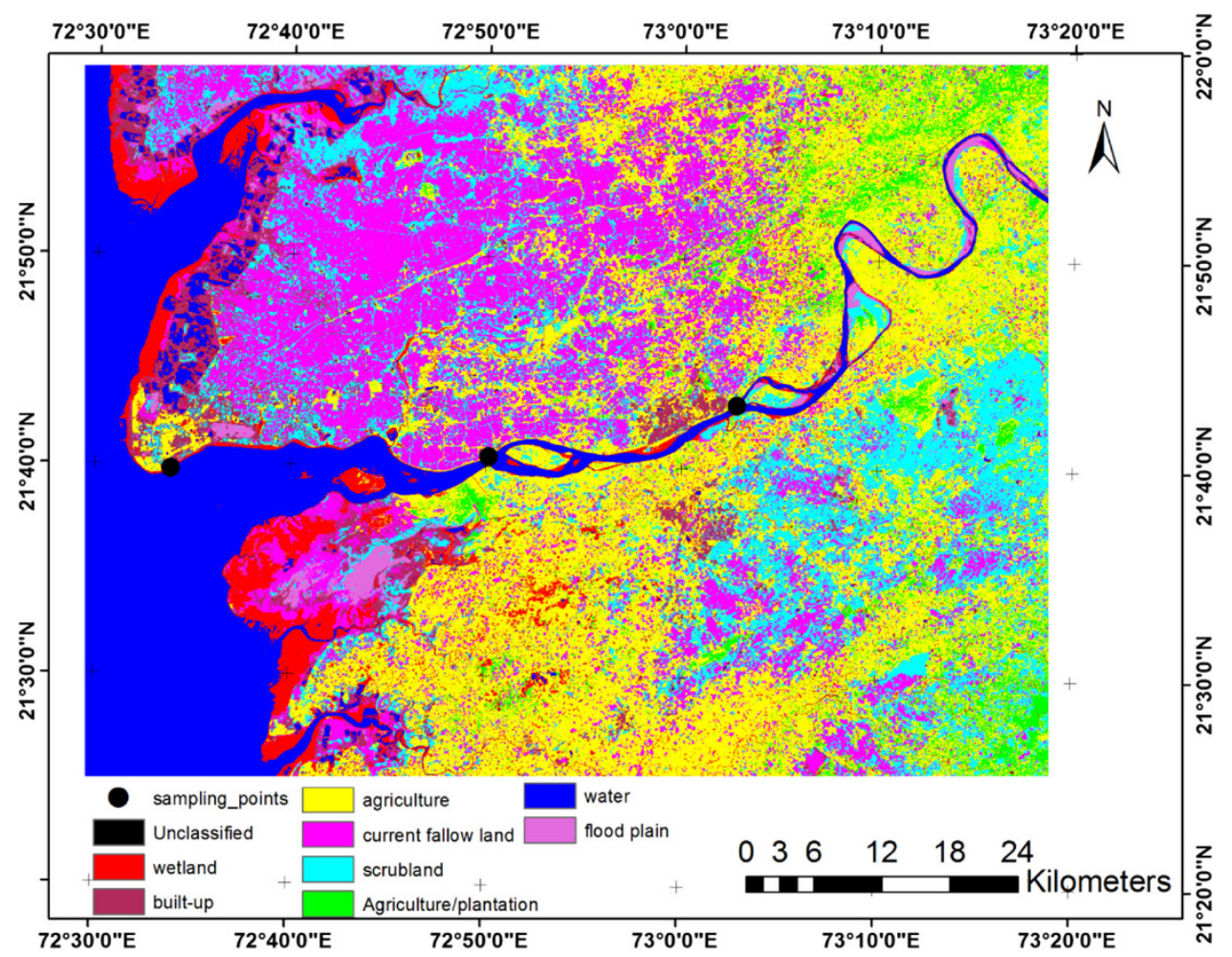

Table 1 Statistical summary for the water chemistry of three locations at Narmada estuarine region

\begin{tabular}{|c|c|c|c|c|c|c|c|c|c|}
\hline \multirow[t]{2}{*}{ Parameters } & \multicolumn{3}{|c|}{ Minimum } & \multicolumn{3}{|c|}{ Maximum } & \multicolumn{3}{|c|}{ Average } \\
\hline & N1 & N2 & N3 & N1 & N2 & N3 & N1 & $\mathrm{N} 2$ & N3 \\
\hline $\mathrm{Na}^{+}(\mathrm{mg} / \mathrm{L})$ & 3881.0 & 205.0 & 60.0 & 6382.0 & 610.0 & 280.0 & 4903.0 & 388.4 & 174.5 \\
\hline $\mathrm{K}^{+}(\mathrm{mg} / \mathrm{L})$ & 100.0 & 40.0 & 5.0 & 255.0 & 100.0 & 55.0 & 174.6 & 74.6 & 27.3 \\
\hline $\mathrm{Ca}^{2+}(\mathrm{mg} / \mathrm{L})$ & 1803.5 & 85.5 & 105.9 & 7442.3 & 435.8 & 457.0 & 3755.7 & 158.4 & 200.9 \\
\hline $\mathrm{Mg}^{2+}(\mathrm{mg} / \mathrm{L})$ & 4154.0 & 11.3 & 17.2 & 787.5 & 83.1 & 117.9 & 1883.9 & 35.0 & 46.8 \\
\hline $\mathrm{HCO}_{3}{ }^{+}(\mathrm{mg} / \mathrm{L})$ & 301.0 & 221.0 & 205.0 & 386.0 & 290.5 & 284.4 & 349.6 & 259.2 & 249.8 \\
\hline $\mathrm{SO}_{4}^{2-}(\mathrm{mg} / \mathrm{L})$ & 659.0 & 130.0 & 48.0 & 2074.0 & 418.0 & 185.0 & 1355.2 & 276.0 & 125.4 \\
\hline $\mathrm{Cl}^{-}(\mathrm{mg} / \mathrm{L})$ & 7512.0 & 319.1 & 35.1 & 9765.0 & 1185.7 & 155.8 & 8570.9 & 870.0 & 94.7 \\
\hline
\end{tabular}

in situ analysis, water samples were filtered by $0.20-\mu \mathrm{m}$ Millipore filter paper and then collected in pre-rinsed clean polyethylene bottles, followed by storage at $4{ }^{\circ} \mathrm{C}$ to minimize chemical alterations.

The concentration of $\mathrm{HCO}_{3}{ }^{-}$was determined by acid titration while other anions $\mathrm{Cl}^{-}, \mathrm{NO}_{3}{ }^{-}, \mathrm{SO}_{4}{ }^{2-}, \mathrm{Br}^{-}, \mathrm{PO}_{4}{ }^{3-}$ were analyzed by DIONEX ICS-90 ion chromatograph with an error percentage of $<2 \%$ using duplicates. Major cations and trace elements were determined with inductively coupled plasma mass spectrometry with a precision of $<1 \%$ using duplicates. High-purity reagents (Merck) and milli-Q water (Model Milli-Q, Biocel) were used for all the analysis. For major ions, analytical precision was checked by normalized inorganic charge balance (Kumar et al. 2010; Appelo and Postma 2005). This is defined as
$\left[\left(\mathrm{Tz}^{+}-\mathrm{Tz}^{-}\right) /\left(\mathrm{Tz}^{+}+\mathrm{Tz}^{-}\right)\right]$and represents the fractional difference between total cations and anions. In general, samples showed a charge imbalance mainly in favor of positive charge. The observed charge balance supports the quality of the data points, which is better than $\pm 5 \%$. Presentation of geochemical data in the form of Piper diagram which is helpful to recognize and differentiate various water facies is drawn using the AqQA software (RockWare) (Avtar et al. 2013).

\section{Results and discussion}

A statistical summary of the analytical results (average, minimum and maximum) for water quality characteristic 
Fig. 5 Piper diagram showing temporal variation in water quality for sample N1

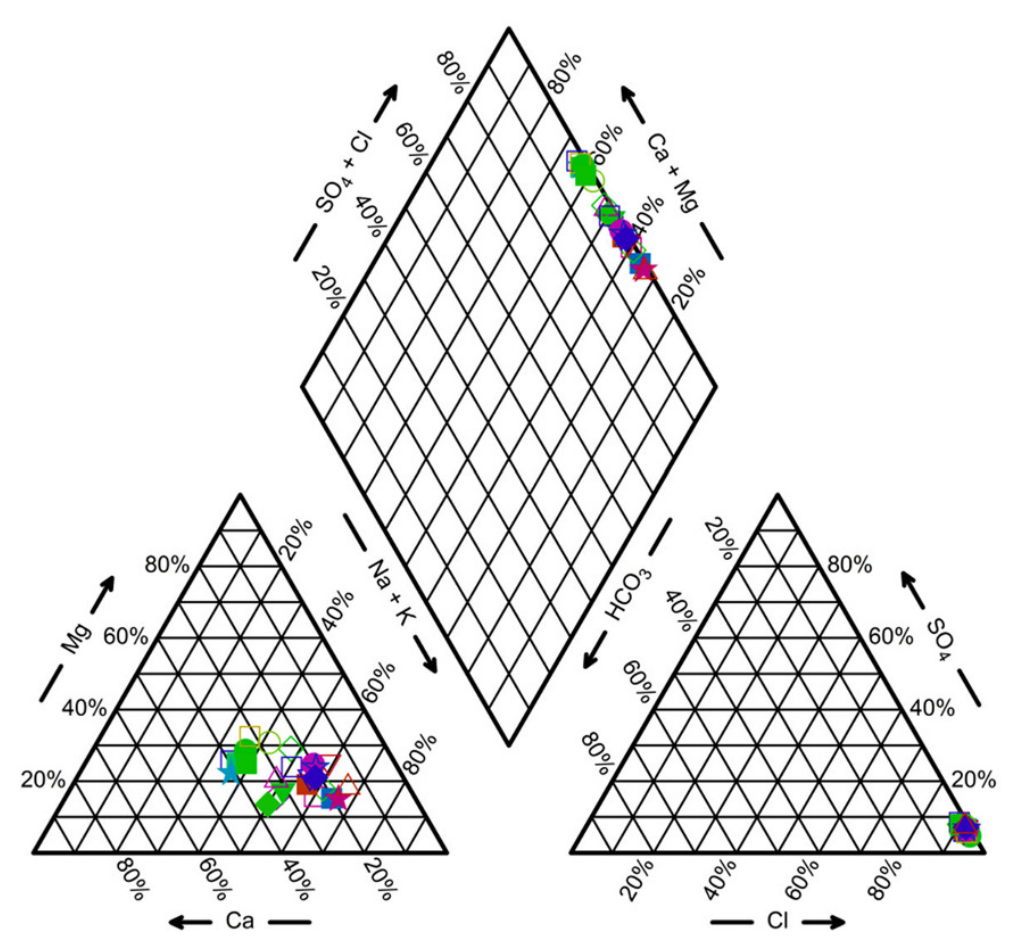

Legend

$\diamond \mathrm{N} 1(0708)$

$\checkmark \mathrm{N} 1(0808)$

- N1(0908)

$\square \mathrm{N} 1(1008)$

$\star \mathrm{N} 1(1108)$

V N1(1208)

- N1(0109)

$\square \mathrm{N} 1(0209)$

- N1(0309)

N1(0409)

$\nabla \mathrm{N} 1(0509)$

- N1(0609)

$\star \mathrm{N} 1(0709)$

$\triangle \mathrm{N} 1(0809)$

$\triangle \mathrm{N} 1(0909)$

$\square \mathrm{N} 1(1009)$

$\nabla \mathrm{N} 1(1109)$

$\square \mathrm{N} 1(1209)$

- N1(0110)

$\mathrm{N} 1(0210)$

- N1(0310)

25 $\mathrm{N} 1(0410)$

- N1(0510)

$\triangle \mathrm{N} 1(0610)$

Fig. 6 Piper diagram showing temporal variation in water quality for sample N2
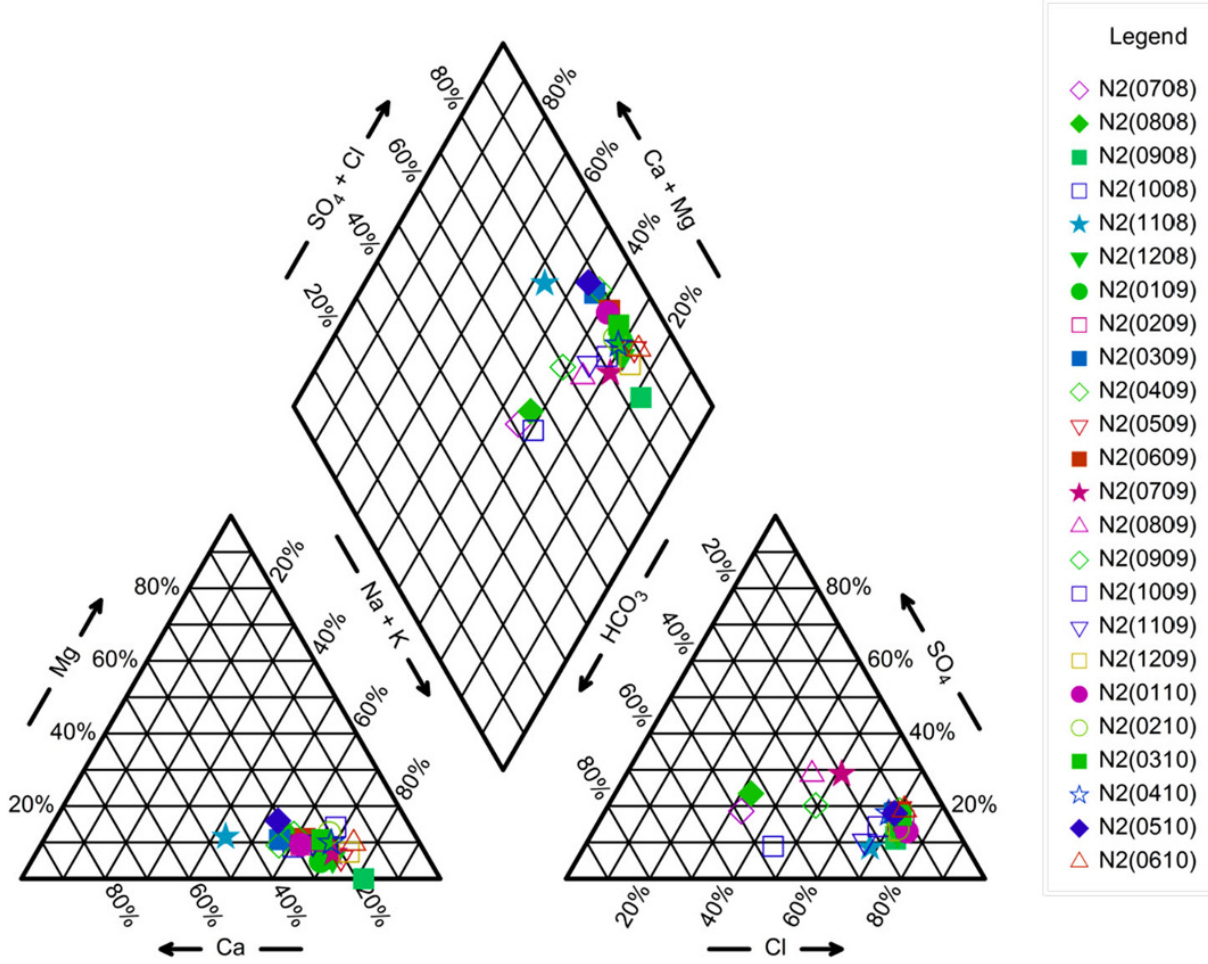

analyzed in terms of major ions is shown in Table 1. For Narmada estuarine region, general water chemistry is characterized by different ionic trend at different location. The orders for cations are $\mathrm{Na}^{+}>\mathrm{Ca}^{2+}>\mathrm{Mg}^{2+}>\mathrm{K}^{+}$, $\mathrm{Na}^{+}>\mathrm{Ca}^{2+}>\mathrm{K}^{+}>\mathrm{Mg}^{2+}$ and $\mathrm{Ca}^{2+}>\mathrm{Na}^{+}>\mathrm{Mg}^{2+}>\mathrm{K}^{+}$for $\mathrm{N} 1, \mathrm{~N} 2$ and N3, respectively. Similarly, the orders for anions are $\mathrm{Cl}^{-}>\mathrm{SO}_{4}{ }^{2-}>\mathrm{HCO}_{3}{ }^{-}, \mathrm{HCO}_{3}{ }^{-}>\mathrm{Cl}^{-}>\mathrm{SO}_{4}{ }^{2-}$ and $\mathrm{HCO}_{3}{ }^{-}>\mathrm{SO}_{4}{ }^{2-}>\mathrm{Cl}^{-}$for $\mathrm{N} 1, \mathrm{~N} 2$ and $\mathrm{N} 3$, respectively.

As estuarine zones are confluence of fresh and saline water system, sharp gradation of water quality while approaching toward coast from inland gives an idea about 
Fig. 7 Piper diagram showing temporal variation in water quality for sample N3
Fig. 8 Time series plot to show relationship between tidal height, average monthly rainfall and $\mathrm{Na}$ for different samples

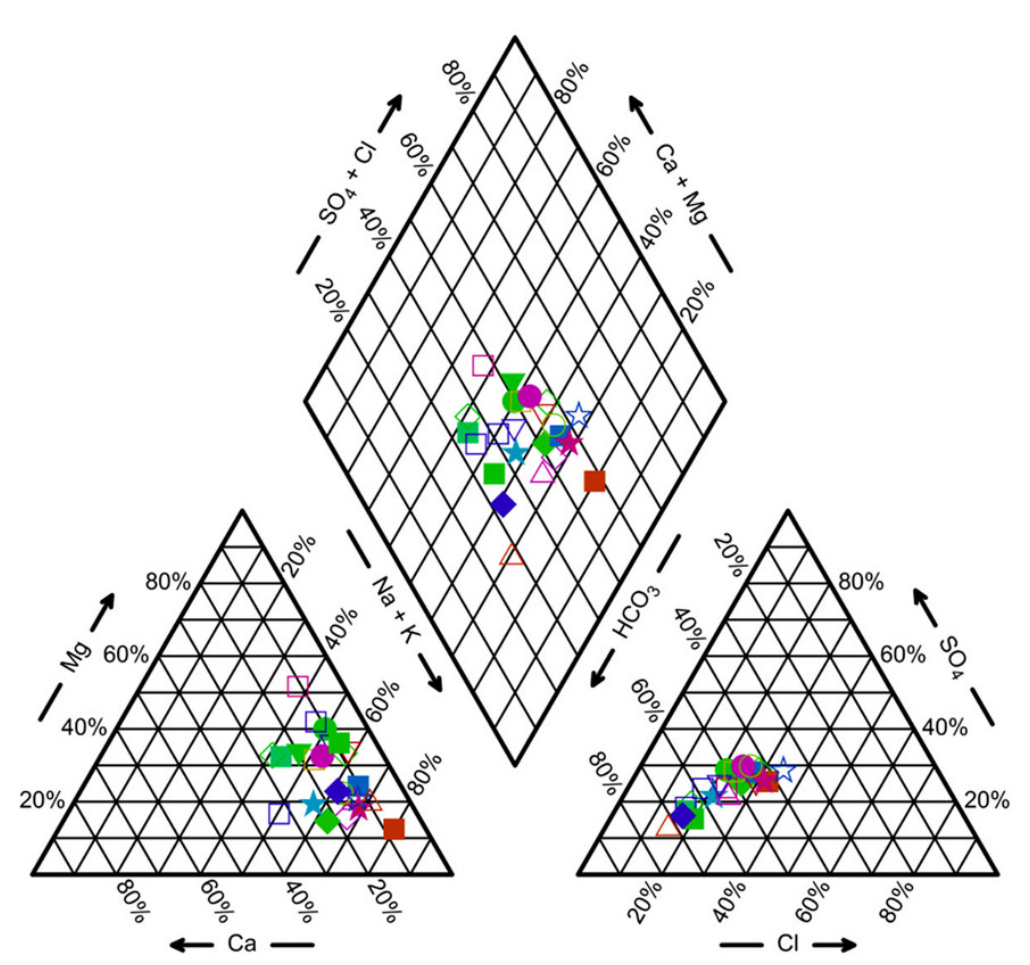

Legend

$\diamond \mathrm{N} 3(0708)$

N3(0808)

- N3(0908)

$\square \mathrm{N} 3(1008)$

$\star N 3(1108)$

$\nabla \mathrm{N} 3(1208)$

- N3(0109)

$\square \mathrm{N} 3(0209)$

- N3(0309)

$\diamond \mathrm{N} 3(0409)$

$\nabla \mathrm{N} 3(0509)$

- N3(0609)

$\star \mathrm{N} 3(0709)$

$\triangle N 3(0809)$

$\mathrm{N} 3(0909)$

$\square \mathrm{N} 3(1009)$

$\nabla \mathrm{N} 3(1109)$

N3(1209)

- N3(0110)

$\mathrm{N} 3(0210)$

- N3(0310)

结 $\mathrm{N} 3(0410)$

- N3(0510)

$\triangle \mathrm{N} 3(0610)$

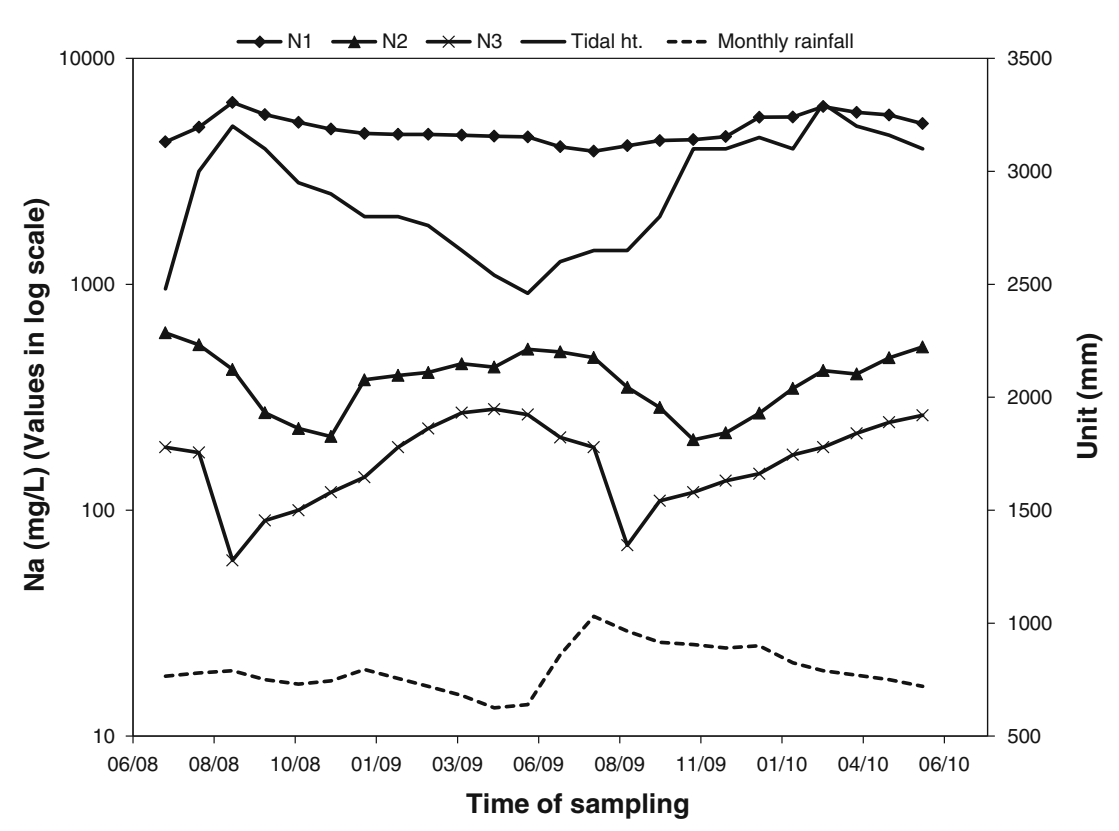

the effect of land use/landscape along with different mixing pattern at that point. Different land use/landscape acts as recipients/reservoirs of different pollutants. Demonstration of geochemical data in the form of graphical chart such as Piper diagram is helpful to recognize and differentiate various water facies as well as temporal variation in it. From Piper diagram, it is found that water quality has significant seasonal variation in all three cases (Figs. 5, 6 and 7 for samples N1, N2 and N3, respectively). Majority of the water samples fall in the category of water type of $\mathrm{Na}-\mathrm{Cl}$ (for point $\mathrm{N} 1$ ), $\mathrm{Na}-\mathrm{HCO}_{3}, \mathrm{Na}-\mathrm{Cl}$ and $\mathrm{Ca}-\mathrm{Cl}$ (for point N2) while it was $\mathrm{Ca}-\mathrm{HCO}_{3}$ and $\mathrm{Na}-\mathrm{HCO}_{3}$ in case of point N3. Other minor water type found in case of these samples is $\mathrm{Mg}-\mathrm{HCO}_{3}$. These temporal transformations in the water quality/type might take place because of the factors/processes such as seasonal precipitation amount (as 
Fig. 9 Time series plot to show relationship between tidal height, average monthly rainfall and $\mathrm{Cl}$ for different samples
Fig. 10 Time series plot to show relationship between tidal height, average monthly rainfall and $\mathrm{HCO}_{3}$ for different samples
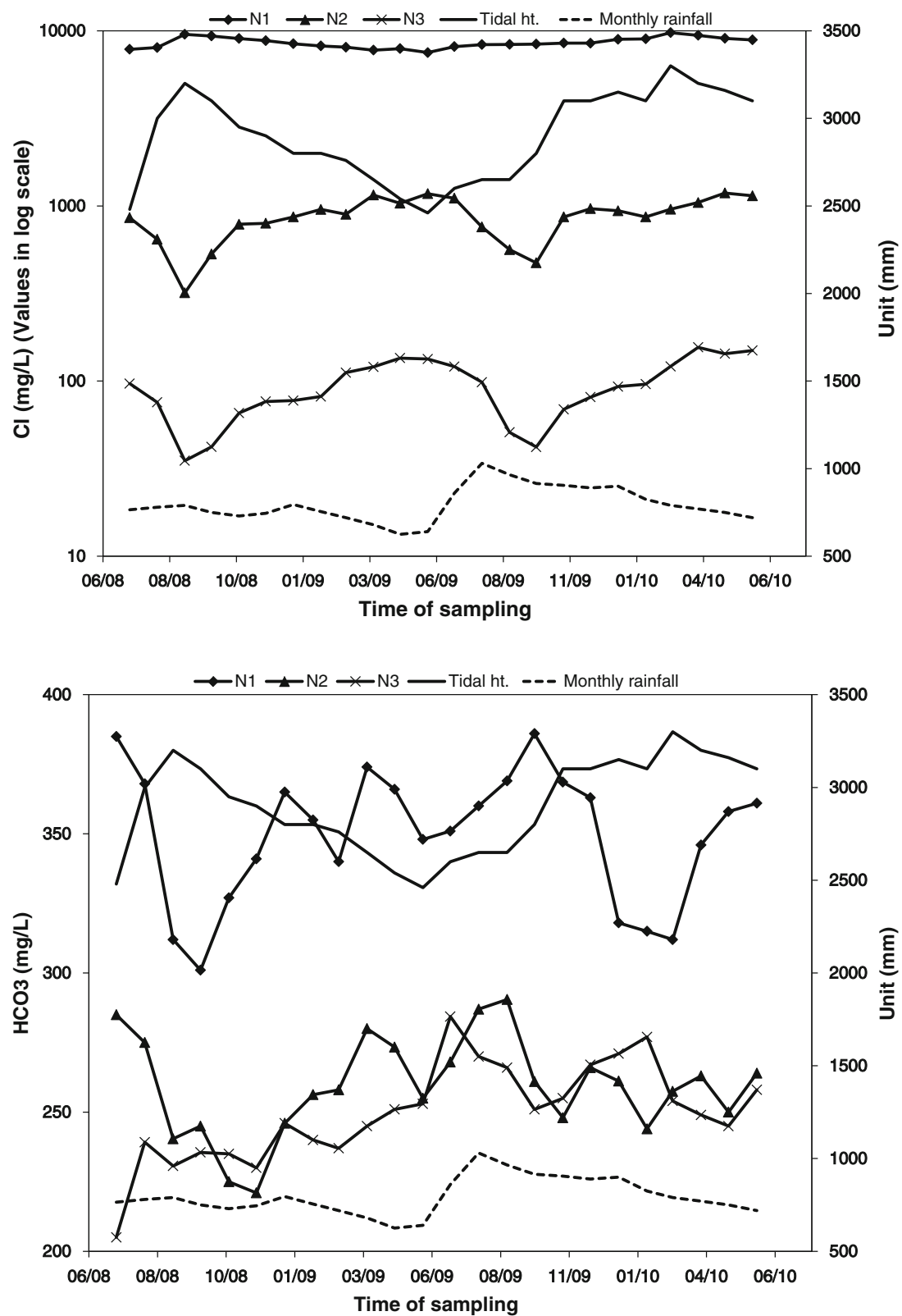

Indian subcontinent climate is monsoon driven), tidal height, groundwater-seawater mixing pattern.

In order to examine the geochemical processes governing the water quality in detail, following further analysis was done.

\section{Relationship between tidal level fluctuation, rainfall and seasonal variation of water quality}

Since water sampling is being done at 15 th day of every month for 2 years, it is found that few month of the sampling period encountered spring tide situation, while at some times, it faces neap tide situation as seen from tidal height. In case of all three water sample points, seasonal variation is very obvious as already being seen from the Piper diagram for the representative samples. Further, monthly fluctuation of major ions was compared with tidal fluctuation and monthly average rainfall pattern in that area (Figs. 8, 9 and 10 for $\mathrm{Na}, \mathrm{Cl}$ and $\mathrm{HCO}_{3}$, respectively). Here, $\mathrm{Na}$ and $\mathrm{Cl}$ are being considered as the conservative elements for coastal region. On the contrary, $\mathrm{HCO}_{3}$ is considered as conservative property for freshwater system.

From above three graphs, it is found that in case of the sample N1, water quality does not show significant variation with rainfall or tidal height except at two points of times which correspond to high tide situations. At this point of time, concentration of $\mathrm{Na}$ and $\mathrm{Cl}$ increases, whereas concentration of $\mathrm{HCO}_{3}$ decreases. Here, it can be suggested that tidal height or localized seawater-freshwater mixing 
Fig. 11 Time series plot to show relationship between tidal and SW-FW mixing ratio (in

$\%$ ) for different samples height, average monthly rainfall

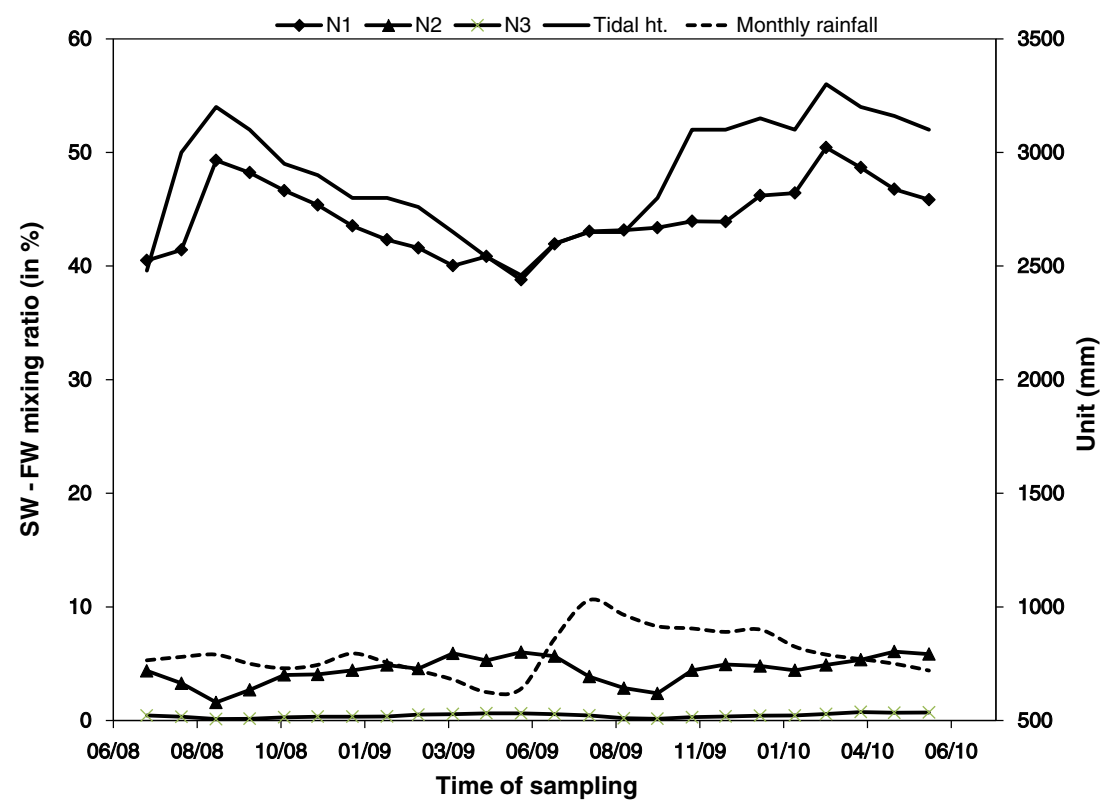

Low tide

Fig. 12 Conceptual sketching showing the mechanisms responsible for spatiotemporal variation in the water quality at Narmada estuarine region

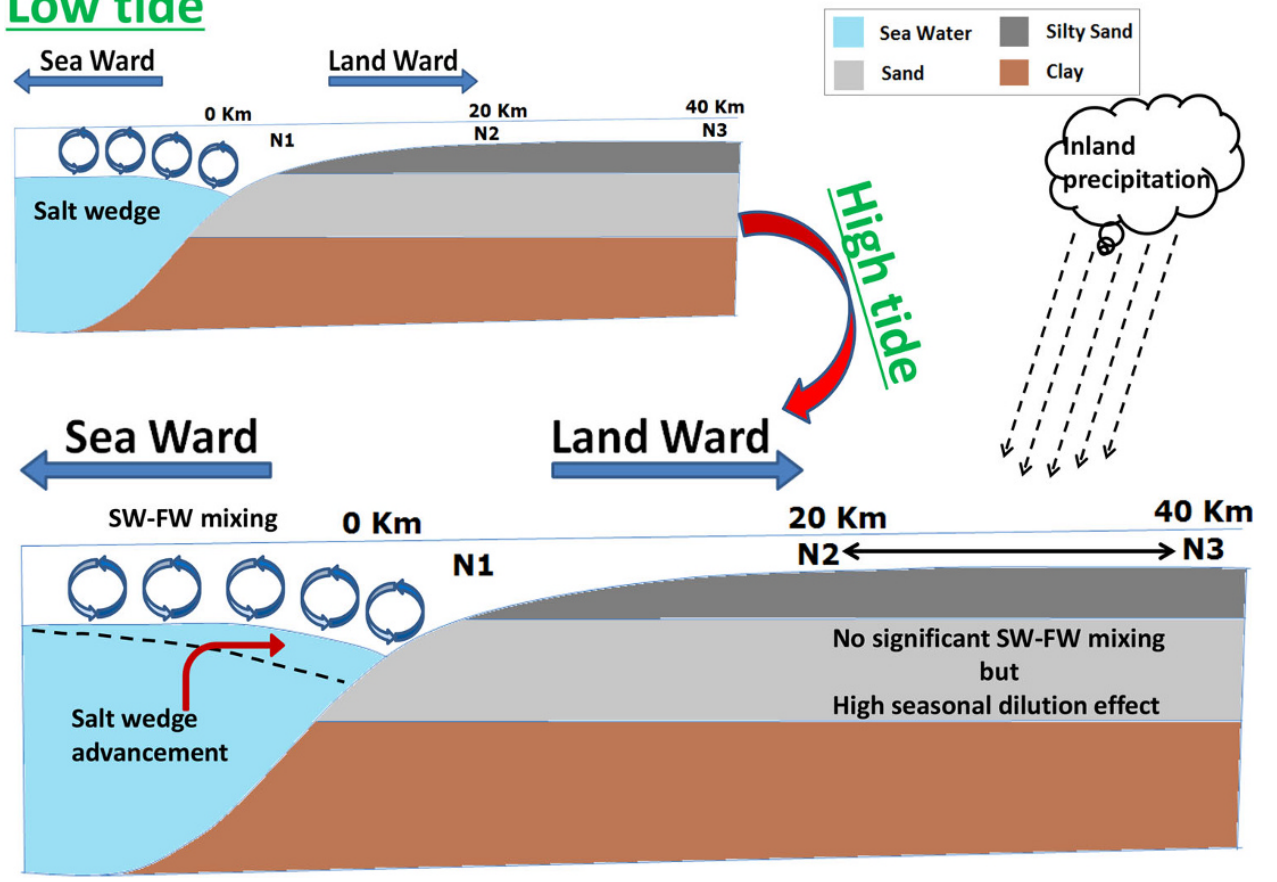

has significant impact on water quality because of its position at close proximity from the coast $(\sim 150 \mathrm{~m}$ from the coast). In other words, during high tide situation, freshwater components decrease or saline water components increase.

In case of sample $\mathrm{N} 2$ and N3, it is found that water quality characteristics show consistent periodic fluctuation. Every year from July to September, concentrations of $\mathrm{Na}$ and $\mathrm{Cl}$ decrease, while those of $\mathrm{HCO}_{3}$ increase. Role of tidal fluctuation for temporal variation of water chemistry here does not look rational as the distance of these sampling points is too far from coast to have a tidal fluctuation effect. On the other hand, significant relation is observed between rainfall pattern and temporal variation in hydrochemistry. Since this area is receiving about 60-70\% of the total rainfall during monsoon period (i.e., from June to September), which results in the dilution of many parameters such as $\mathrm{Na}$ and $\mathrm{Cl}$ as observed from the Figs. 8, 9 and 10. In parallel, because of the high amount of precipitation, the rate of carbonate weathering is accelerated in the alluvial flood plain region, causing increase in the concentration of $\mathrm{HCO}_{3}$ in the water samples. 
Calculation of percentage $\mathrm{SW}-\mathrm{FW}$ mixing rate and its relation with tidal fluctuation

Considering chloride concentration as conservative property for seawater, mixing ratio was calculated using Eq. (1) (Appelo and Postma 2005):

$\mathrm{f}=\frac{\left(\mathrm{Cl}_{\text {Sample }}-\mathrm{Cl}_{\text {Fresh }}\right)}{\left(\mathrm{Cl}_{\text {Sea }}-\mathrm{Cl}_{\text {Fresh }}\right)} \times 100(\%)$

where $\mathrm{f}=$ salt water mixing rate $(\%), \mathrm{Cl}_{\text {Sample }}=$ chloride concentration of sample, $\mathrm{Cl}_{\text {Fresh }}=$ chloride concentration of Narmada River near recharge site (upstream) [i.e., $11.5 \mathrm{mg} / \mathrm{L}$ (Sharma and Subramanian 2008)], and $\mathrm{Cl}_{\text {Sea }}=$ chloride concentration of seawater [i.e., 19,350 mg/L (Kumar et al. 2013)].

Here, chloride concentrations for seawater and Narmada River water (near the river recharge site, i.e., head) were considered as two end members. Result for SW-FW mixing percentage at each sampling location and its relation with tidal height is shown in Fig. 11. From here, it is found that water quality has gradual and significant mixing impact as going toward the sea side; since the value of SW-FW mixing ratio is in the order of $\mathrm{N} 1>\mathrm{N} 2>\mathrm{N} 3$. Also when the effect of tidal height fluctuation on the ratio of SW-FW mixing ratio is compared, it is observed that for point $\mathrm{N} 1$, water quality is affected at its highest level because of close proximity to the sea coast. On the other hand, effect of tidal height on the SW-FW mixing at the other two locations is insignificant. Finally, it can be said that during spring tide situation, sea level rises enhance SW-FW mixing process and determine salinity level of water quality in closer proximity.

Possible mechanism for the role of tidal fluctuation in temporal variation of surface water quality at estuarine region is shown by simple conceptual diagram (Fig. 12). Here, it is shown that for sampling location situated near to the coast (within few hundred meters from the coast), high tide situation results into increased rate of SW-FW mixing which ultimately lead to change in water quality. On the other hand, for sampling points located far from the coast, tidal height does not play a significant role in temporal variation of water chemistry. So, other factors such as dilution effect and rock-water interaction play a role in temporal changing water quality.

\section{Conclusion}

For Narmada estuarine region, general water chemistry is characterized by different ionic trend at different location. The order for cations are $\mathrm{Na}^{+}>\mathrm{Ca}^{2+}>\mathrm{Mg}^{2+}>\mathrm{K}^{+}$, $\mathrm{Na}^{+}>\mathrm{Ca}^{2+}>\mathrm{K}^{+}>\mathrm{Mg}^{2+}$ and $\mathrm{Ca}^{2+}>\mathrm{Na}^{+}>\mathrm{Mg}^{2+}>\mathrm{K}^{+}$for
N1, N2 and N3, respectively. Similarly, the order for anions are $\mathrm{Cl}^{-}>\mathrm{SO}_{4}{ }^{2-}>\mathrm{HCO}_{3}{ }^{-}, \mathrm{HCO}_{3}{ }^{-}>\mathrm{Cl}^{-}>\mathrm{SO}_{4}{ }^{2-}$ and $\mathrm{HCO}_{3}{ }^{-}>\mathrm{SO}_{4}{ }^{2-}>\mathrm{Cl}^{-}$for $\mathrm{N} 1, \mathrm{~N} 2$ and $\mathrm{N} 3$, respectively. Spatiotemporal variation of water quality occurs because of following main mechanisms, i.e., carbonate weathering, dilution and SW-FW mixing.

Firstly, points situated in the inner part of the estuary show the dilution effect as a result of a high amount of monsoonal precipitation. Secondly, tidal fluctuation pattern has a strong influence on the water quality only for the point located in near proximity to the coast. Magnitude of this effect diminishes as moving landward from the coast.

Though differences in magnitude of many chemical parameters caused by these processes are not high, the process is significantly to be pointed out. This work represents the first attempt to describe this kind of processes at the Narmada estuary, and the information revealed here can be considered important to understand the relationships between groundwater and river dynamics in this area.

Acknowledgments Authors would like to thank CIF facilities at ISTAR for allowing them the logistic support to conduct experiments for water samples.

Open Access This article is distributed under the terms of the Creative Commons Attribution License which permits any use, distribution, and reproduction in any medium, provided the original author(s) and the source are credited.

\section{References}

Abdullah MH, Mokhtar MB, Tahir SHJ, Awaluddin ABT (1997) Do tides affect water quality in the upper phreatic zone of a small oceanic island, Sipadan Island, Malaysia? Environ Geol 29(1/ 2):112-117

Appelo CAJ, Postma D (2005) Geochemistry, groundwater and pollution, 2nd edn. Balkema, The Netherlands, p 649

Avtar R, Kumar P, Surjan A, Gupta LN, Roychowdhury K (2013) Geochemical processes regulating groundwater chemistry with special reference to nitrate and fluoride enrichment in Chhatarpur area, Madhya Pradesh, India. Environ Earth Sci 70:16991708

Cameron WM, Pritchard DW (1963) Estuaries. In: Hill MN (ed) The sea, vol 2. Wiley, New York, pp 306-324

Chen NS, Sanford LS (2009) Lateral circulation driven by boundary mixing and the associated transport of sediments in idealized partially mixed estuaries. Cont Shelf Res 29:101-118

De Souza SN (1983) Study on the behaviour of nutrients in the Mandovi estuary during premonsoon-Estuarine. Coast Shelf Sci 16:299-308

Eagling J, Worsfold PJ, Blake WH, Keith-Roach MJ (2012) Mobilization of technetium from reduced sediments under seawater inundation and intrusion scenarios. Environ Sci Technol 46(21):11798-11803

Fairbridge RW (1980) The estuary: its definition and geodynamic cycle. In: Cato I, Olausson E (eds) Chemistry and biogeochemistry of estuaries. Wiley, New York, pp 1-35 
Grant US (1948) Influence of the water table on beach aggradation and degradation. J Marine Res 7:655-660

Harbison P (1986) Diurnal variation in the chemical environment of a shallow tidal inlet, Gulf St Vincent, South Australia: implication for water quality and trace metal migration. Mar Environ Res 20:161-195

ICMAM (2002) Critical habitat information system for Gulf of Khambhat- Gujarat. Department of Ocean Development, Government of India, Delhi

Jorgensen NO, Andersen MS, Engesgaard P (2008) Investigation of a dynamic seawater intrusion event using strontium isotopes $\left({ }^{87} \mathrm{Sr} /{ }^{86} \mathrm{Sr}\right)$. J Hydrol 348:257-269

Kumar P, Kumar M, Ramanathan AL, Tsujimura M (2010) Tracing the factors responsible for arsenic enrichment in groundwater of the middle Gangetic Plain, India: a source identification perspective. Environ Geochem Health 32:129-146

Kumar P, Tsujimura M, Nakano T, Minoru T (2012) The effect of tidal fluctuation on ground water quality in coastal aquifer of Saijo plain, Ehime prefecture, Japan. Desalination 286:166-175

Kumar P, Tsujimura M, Nakano T, Minoru T (2013) Time series analysis for the estimation of tidal fluctuation effect on different aquifers in a small coastal area of Saijo plain, Ehime prefecture, Japan. Environ Geochem Health 35:239-250

Langman JB, Ellis AS (2010) A multi-isotope $\left(\delta \mathrm{D}, \delta 18 \mathrm{O},{ }^{87} \mathrm{Sr} /{ }^{86} \mathrm{Sr}\right.$, and $\delta^{11} \mathrm{~B}$ ) approach for identifying saltwater intrusion and resolving groundwater evolution along the Western Caprock Escarpment of the Southern High Plains, New Mexico. Appl Geochem 25:159-174

Li L, Barry A, Parlange JY, Pattiaratchi CB (1997) Beach water table fluctuation due to wave run-up: capillary effects. Water Resour Res 33(5):935-945

Manca F, Capelli G, La Vigna F, Mazza R, Pascarella A (2014) Wind-induced salt-wedge intrusion in the Tiber river mouth (Rome-Central Italy). Environ Earth Sci. doi:10.1007/s12665013-3024-5

Prandle D (2009) Estuaries: dynamics, mixing, sedimentation and morphology. Cambridge University Press, UK

Sharma SK, Subramanian V (2008) Hydrochemistry of the Narmada and Tapti Rivers, India. Hydrol Process 22:3444-3455

Turner I (1993) The total water content of sandy beaches. J Coast Res 15:11-26

Wen L, Jiann K, Liu K (2008) Seasonal variation and flux of dissolved nutrients in the Danshuei Estuary, Taiwan: a hypoxic subtropical mountain river. Estuar Cost Shelf Sci 78:694-704

Wong VNL, Johnston SG, Burton ED, Bush RT, Sullivan LA, Slavich PG (2013) Seawater-induced mobilization of trace metals from Mackinawite-rich estuarine sediments. Water Res 47(2):821-832 